\title{
Remote sensing-based fire frequency mapping in a savannah rangeland.
}

\author{
Samuel Kusangaya ${ }^{1}$ and Vhusomuzi .B. Sithole ${ }^{2}$ \\ ${ }^{1}$ Centre for Water Resources Research, University of KwaZulu Natal, Scottsville, \\ Pietermaritzburg 3209, South Africa. Email: kusangayas@yahoo.com \\ ${ }^{2}$ Department of Geosciences, Nelson Mandela Metropolitan University, Summerstrand, Port \\ Elizabeth 6001, South Africa. Email: sitholevb@gmail.com
}

DOI: http://dx.doi.org/10.4314/sajg.v4i1.3

\begin{abstract}
Burnt area mapping and fire frequency analysis were carried out in Hwange National Park, Zimbabwe. Hwange National Park typifies a savannah ecosystem which is semi-arid and fire-prone. This paper presents a geospatial analysis to quantify the spatial distribution and fire frequency from 2000 to 2006. Moderate Resolution Imaging Spectroradiometer (MODIS) images from 2000 to 2006 were obtained and classified for burnt area mapping. Linear pixel unmixing was used for image classification and subsequent mapping of burnt areas. The results showed that it was feasible to have discrimination of burnt areas and 'un-burnt' areas as well as generating a six year fire frequency map of the study area. Accuracy assessment of the classified images was carried out using field obtained information on fire occurrence to validate the classification results. An error matrix quantified accuracy of classified maps through producer's accuracy, user's accuracy and overall accuracy. High overall accuracy rates of appromately 96\%, in turne, justify use of linear pixel unmixing in identifying and mapping burnt areas. Thus pixel unmixing offers a viable mapping tool for fire monitoring and management in protected areas.
\end{abstract}

\section{Introduction}

The increasing temperatures and decreasing precipitation, in Southern Africa's savannah region, will continue to impact heavily on its fire regime (Kusangaya et al., 2013, Pricope and Binford, 2012). These changes will in turn affect the ecology, structure, and function of the savannah ecosystem. In most cases, fires in these ecosystems occur as wild fires (Pricope and Binford, 2012). Fire is a significant factor in determining the ecology of savannahs, boreal forests, and tundra ecosystems (Dwyer et al., 1999). Fires on the African savannah burn large areas of vegetation annually (Dwyer et al., 2000) and this led to it being identified as one of the major threats causing the loss of forests in sub-Saharan Africa (Silva et al., 2003). On the other hand, wild fires play a critical role in ecosystem functioning such as offsetting plants 
and grass regeneration through providing ideal germination and growth conditions (Masocha et al., 2011). The fires, especially in the savannah biome, have led to Africa often being referred to as the "fire continent" (Navashni, 2003).

The savannah ecosystem covers approximately $50 \%$ of the land surface in Africa and is characterized by the coexistence of both grasses and trees (Scholes and Walker, 1993). Burning in the savannah, therefore, has regional and global impacts since fires emit large amounts of greenhouse gasses and aerosol particles (Andreae, 1997, Crutzen and Andreae, 1990) and can lead to changes in vegetation cover (Louppe et al., 1995). Frequent burning of the savannah is also thought to result in land degradation and loss of biodiversity (Masocha et al., 2011) e.g. through allowing invasion by alien invasive species. This calls for the development of an efficient and accurate system to map and monitor burnt areas caused by savannah fires. Although fire monitoring has been given priority by numerous international research organisations (Justice, 1994, Roy et al., 2005), in Zimbabwe biomass burning has continued to increase in the past decades (Tafengenyasha, 1997, Gambiza et al., 2005, Gandiwa and Kativu, 2009).

The causes of wild fires differ with ecosystems which are generally grouped into natural and human-induced ones. These fires are mainly due to lightning (natural) as well as intentionally set incendiary fires (human-induced) (Silva et al., 2003). Humans caused wild fires are mostly through agricultural land clearings, rangeland management, and burning of agricultural residues (Brivio et al., 1999). The global impact of fire on atmospheric chemistry, strong relationships with biogeochemical cycles and implications on climate change are now widely recognised (Goldammer, 1990, Levine, 1991, Crutzen and Goldammer, 1993, Levine, 1996). Vegetation fires account for roughly half of the atmospheric constituents of hydrocarbon, carbon monoxide, nitrogen oxides; all precursors of tropospheric ozone (Crutzen and Andreae, 1990). As a result fire information is useful in driving regional emission models, trace gas transport models, and meso-scale models of atmospheric chemistry (Dwyer et al., 1999).

In Hwange National Park, fire is a ubiquitous terrestrial disturbance factor mostly resulting from anthropogenic activities within or adjacent to the park (Tafengenyasha, 1997). Although Southern Africa experiences one of the worst biomass burning in the world (Dwyer et al., 1999), more research is still required on this environmental phenomenon since the impact of fires remain poorly addressed in fire ecology studies (Masocha et al., 2011), especially at local management levels. Different satellite image products have been used for mapping burnt areas. Examples include the Global Burn Scar (GLOBSCAR) (Simon et al., 2004), Global Burnt Area - 2000 initiative (GBA2000) (Tansey et al., 2004) and the MODIS burnt 
area product (Justice et al., 2002, Roy et al., 2002). The Global VGT burnt area product 2000 -2007 (L3JRC) is available globally on a daily basis and is based on SPOT Vegetation imagery (Tansey, 2007). Furthermore, long-term observations of active fires derived from space borne sensors are available. These include the Along-Track Scanning Radiometer (ATSR) night time fire product (Arino and Rosaz, 1999), the Visible and Infrared Scanner (VIRS) monthly fire product (Giglio et al., 2003), the Moderate Resolution Imaging Spectroradiometer (MODIS) global fire product (Justice et al., 2002), and the Geostationary Operational Environmental Satellite (GOES) Wildfire Automated Biomass Burning Algorithm (WF ABBA) fire product (Prins et al., 1998). Of these, the MODIS Fire Products are designed to provide information for both global change science and practical management applications (Justice et al., 2002, Kaufman et al., 1998). However, because of the global focus of most of these products, there are no adequate data on the regional occurrence, size distributions or trends in fire numbers or areas burnt annually that meet the information needs of policy and decision-makers (Frost, 1999) at local level such as park management. Hence the thrust of this study, to map and determine fire frequency in Hwange National Park, Zimbabwe at the regional level at which fire management is carried out.

\section{Materials and Methods}

\subsection{Study area}

Hwange National Park, founded in 1928, is situated in the North-West of Zimbabwe extending from $17^{\circ} 48^{\prime}$ South, $25^{\circ} 15^{\prime}$ East to $19^{\circ} 52^{\prime}$ South and $26^{\circ} 42^{\prime}$ East. It is Zimbabwe's largest game park covering an area of approximately $14,600 \mathrm{~km}^{2}$. The park is bounded by Botswana in the West, Matetsi and Deka safari areas in the North, state forest land and farms in the North-east and Tsholotsho communal land in the South-East (Figure 1). 


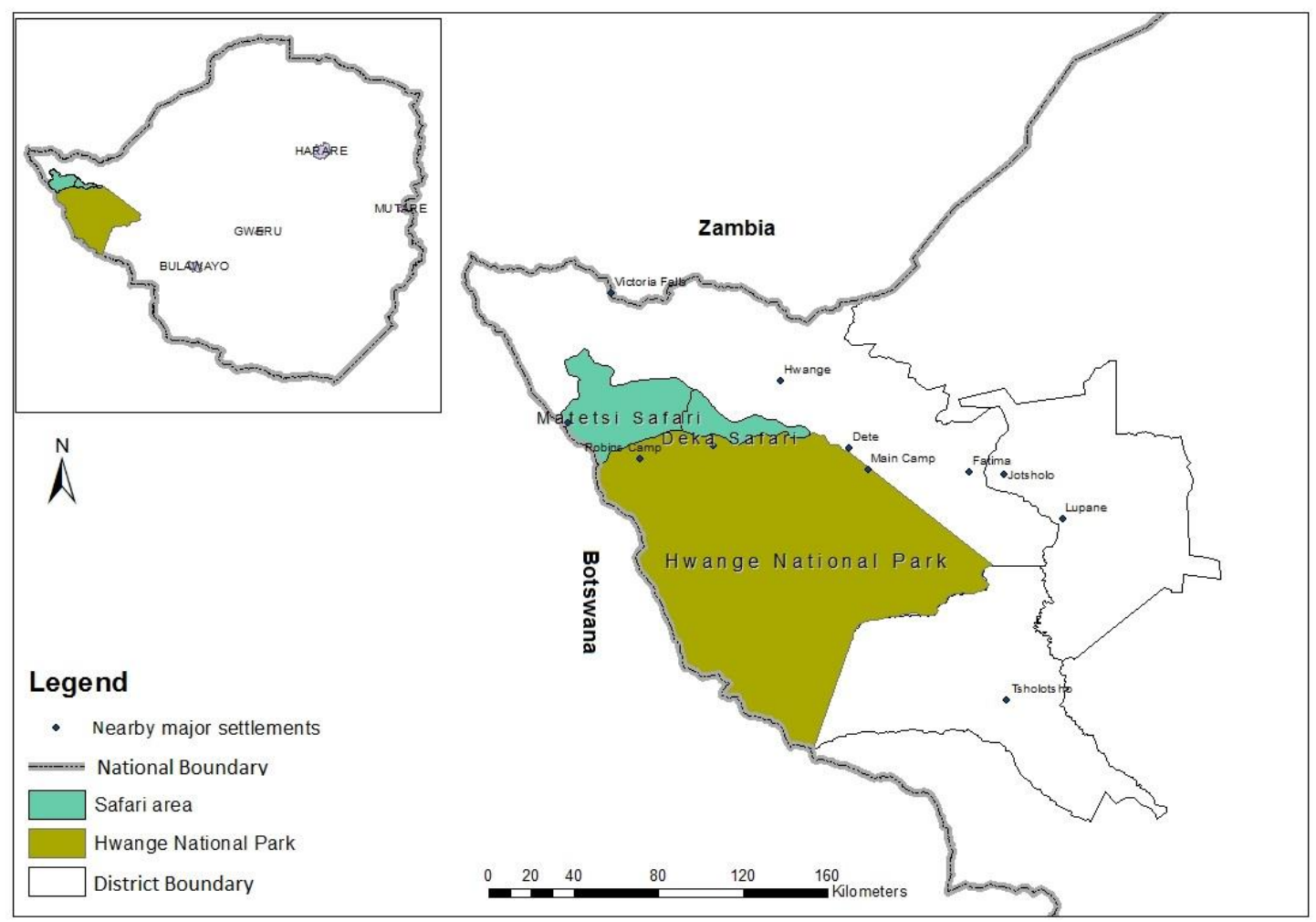

Figure 1: Location of Hwange National Park in Zimbabwe

Vegetation of the park comprises mixed woodlands and shrub lands of Bairkiea plurijuga, Combretums, Acacias and Terminalia sericea (Marion et al., 2006). Generally, the woodland vegetation of the park is dominated by Baikiea plurijuga, Baphia massaiensis and Kalahari bauhinia. However, in the north and north-west of the park mopane woodland (Guibourtia coleosperma) is more dominant (Cumming et al., 1997, Hyde et al., 2010). The park receives a mean annual rainfall of about $620 \mathrm{~mm}$ and mean annual temperature range is $7{ }^{\circ} \mathrm{C}-35^{\circ} \mathrm{C}$. It is coolest between May to August while September to March are the warmest months. The dry season occurs in April through October and the wet season occurs from November to March. In the dry season, temperatures get as high as $33^{\circ} \mathrm{C}$ (in October) and this period coincides with fire occurrence in the park.

Currently, fire management and mitigation activities are highly dependent upon the knowledge and intuition of fire management personnel. Fire management and mitigation within the park is guided by the main fire policy of the Parks and Wildlife Authority of Zimbabwe. Within the park, establishment and maintenance of 'fireguards' is one of the main tools of fire control and prevention. These strategies are enshrined in the Parks and Wildlife Act of 1991 (Parks and Wildlife Act, 1991). Fire mitigation outside the park is enforced through the Forest Act of 1990 (Forest Act, 1990) and the Environmental Management Act of 
2002 (Environmental Management Act, 2002). Both Acts regulate the burning and preventive measures used to supress and control the spread of wildfires.

\subsection{Data}

MODIS is a satellite sensor instrument mounted on NASA's Terra Earth Observing System (EOS AM) and Aqua Earth Observing System (EOS PM) satellites. Image bands 1 $(620-670 \mathrm{~nm})$ and $2(841-876 \mathrm{~nm})$ of MODIS with a spatial resolution of $250 \mathrm{~m}$ (NASA, 2013) were used. These image bands were selected because MODIS's multi-spectral capabilities in the visible and near-infrared regions and narrow spectral bands have an advantage of improved spatial resolution compared to National Oceanic and Atmospheric Administration (NOAA)'s Advanced Very High Resolution Radiometer (AVHRR), previously widely used for burnt area mapping. October images were selected, before the onset of the rainy season and which coincidentally marks the end of the fire season in Zimbabwe (Silva et al., 2003). As such the resultant burnt area maps were assumed to be representative of the burning that would have occurred during the whole fire season from May to October. Hence the estimated burnt areas derived from each of the satellite images were a good estimation of the spatial distribution of burnt areas for each year's fire season. All the MODIS October images covering Hwange National Park for the years from 2000 to 2006 were subsequently processed for burnt area mapping.

\subsection{Remote sensing}

Traditional multispectral classification techniques are based on the spectral properties of different classes of interest and employ parametric classification algorithms based on Bayes' theorem which originates from probability theory. These techniques include the Maximum likelihood, Minimum Distance, Parallelepiped (Box), Minimum Mahalanobis Distance, ISODATA and the K-Means (Wang and Jia, 2009) classification methods. These algorithms lead to the assignment of each pixel to a single class thereby making assumptions of pure (Foody, 2002), discrete and mutually exclusive pixels (Congalton and Green, 2008) which in the real world do not exist. In coarser multispectral imagery, these assumptions are difficult to fulfil due to the presence of mixed pixels (Campbell, 1996, Wang and Jia, 2009). On the other hand, linear pixel unmixing has shown great promise in overcoming the identified shortcomings. Thus linear pixel unmixing was employed for this study.

\subsubsection{Linear pixel unmixing}

Spectral unmixing is a quantitative analysis procedure used to recognise constituent ground cover materials (or end members) and obtain their mixing proportions (or abundances) from a mixed pixel (Keshava, 2003). Spectral unmixing was chosen due to its ability to indicate fractions, abundances or proportion of each end member within a mixed 
pixels (Xin et al., 2006, Bateson et al., 2000). Linear unmixing involves two procedures, that is, end member spectra acquisition and proportion estimation (Quintano et al., 2012). The procedure models each spectrum as a combination of a finite number of spectrally distinct signatures (end members), whose coefficients range between 0 and 1 and adding up to 1 (Adams, 1986). This linear mixture model can be mathematically described for a pixel in band i, with the observed pixel reflectance $R_{i}$ as a linear equation [1],

$$
R_{i}=\sum_{i, j=1}^{n} f_{j} a_{i j}+\varepsilon_{i}
$$

Where:

$f_{j}$ is the $\mathrm{j}^{\text {th }}$ fraction of end member in a pixel,

$j$ is total number of end members in the scene,

$a_{i j}$ is the pure reflectance from the $j^{\text {th }}$ end members in the $i^{\text {th }}$ pixel,

$\varepsilon_{\mathrm{i}}$ is an error term.

Only two end members from the image namely 'burnt' areas and 'un-burnt' areas were used. The end members were selected from the image after the image dimension had been reduced using the minimum noise fraction (MNF). The MNF transform is used to segregate and equalise the noise in the data, and reduce the computational requirements for subsequent processing (ENVI, 2006). After MNF, the bands containing 'noise' are not used in subsequent processing. Figure 2 below illustrates the concept for 2-dimensional plots used to locate end members. The end members ('burnt' and 'un-burnt' areas) are clearly separable, using band 1 and band 2 with little noise. Linear spectral unmixing was therefore subsequently used to find the abundances of 'burnt' and 'un-burnt' areas from the image pixels for the whole park. In cases where it was difficult to select many training samples for burnt areas, region growing techniques were used. In region growing, clusters of active fire pixels derived from the composite active-fire mask were used as seeds to iteratively "fill in" the surrounding burn scar. This enabled mapping of all the burnt areas. 


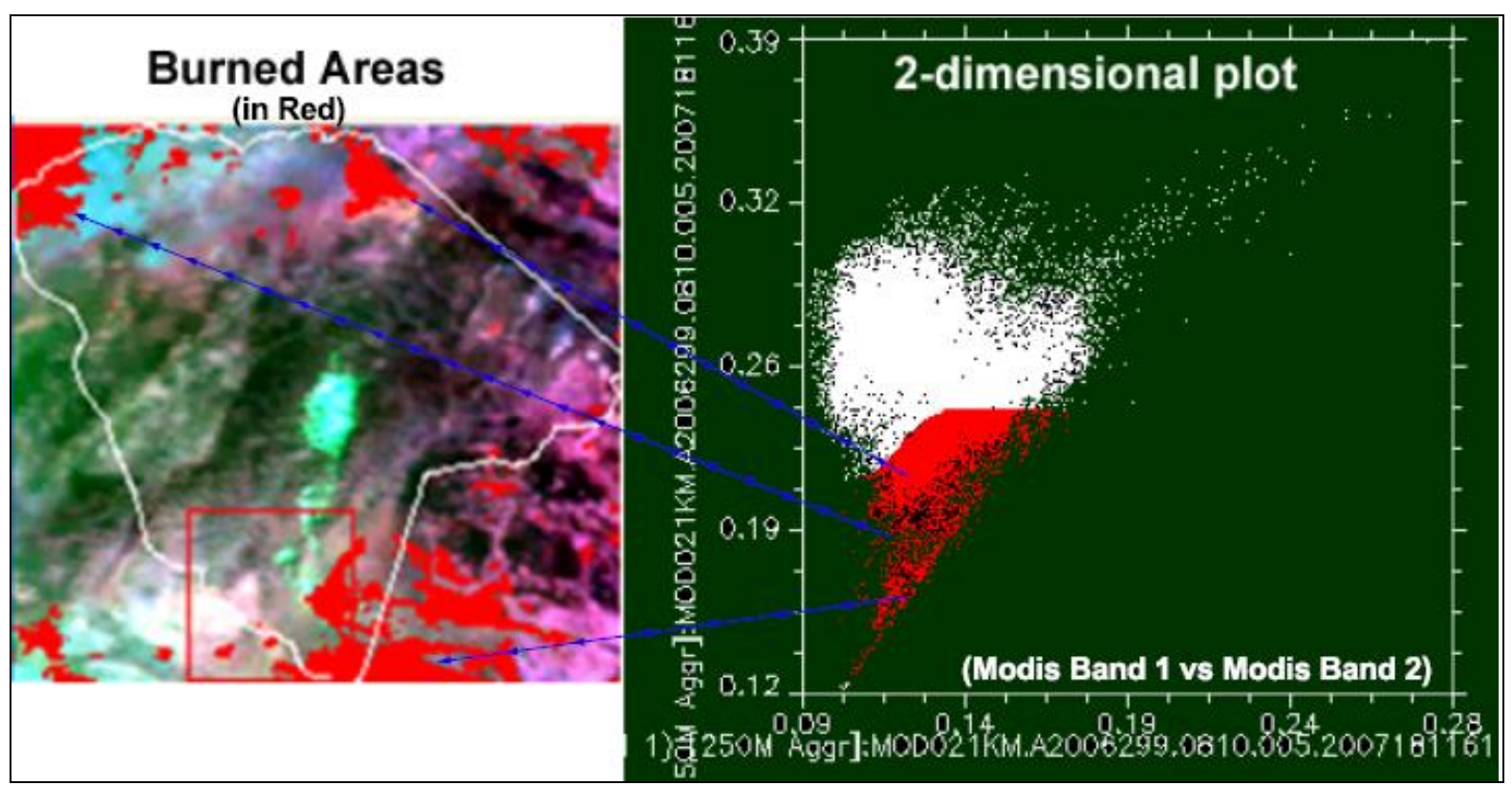

Figure 2: n-Dimensional visualiser used in selecting "pure" endmembers for image classification

\section{Results and Discussion}

Results illustrate that the relative cover of burnt patches could be separated with reasonable accuracy from the 'un-burnt' areas. Table 1 below summarises the total area classified as burnt areas for the years from 2000 to 2006. Overall, for all the years the areas classified as 'un-burnt' was significantly $(\mathrm{p}<0.05)$ higher than the burnt areas in Hwange National Park (Table 1).

Table 1: Total area classified as burnt area

\begin{tabular}{|l|l|l|l|l|}
\hline Year & $\begin{array}{l}\text { Not burnt } \\
\left(\mathbf{k m}^{2}\right)\end{array}$ & $\begin{array}{l}\text { Burnt area } \\
\left(\mathbf{k m}^{2}\right)\end{array}$ & Not burnt $(\%)$ & $\begin{array}{c}\text { Burnt } \\
(\%)\end{array}$ \\
\hline 2006 & 10689.74 & 4047.95 & 72.53 & 27.47 \\
\hline 2005 & 10918.70 & 3818.98 & 74.09 & 25.91 \\
\hline 2004 & 10092.05 & 4645.64 & 68.48 & 31.52 \\
\hline 2003 & 12190.16 & 2547.56 & 82.71 & 17.29 \\
\hline 2002 & 8995.76 & 5741.92 & 61.04 & 38.96 \\
\hline 2001 & 12975.73 & 1761.95 & 88.04 & 11.96 \\
\hline 2000 & 8458.90 & 5680.53 & $\begin{array}{l}57.4 \\
(+4.06 \% \text { from clouds })\end{array}$ & 38.54 \\
\hline
\end{tabular}

On a year by year basis, the years 2000 and 2002 experienced most fires and hence had the highest burnt areas (38.54\% and 38.96\% respectively) (Table 1 and Figure $3 \& 4$ ). 


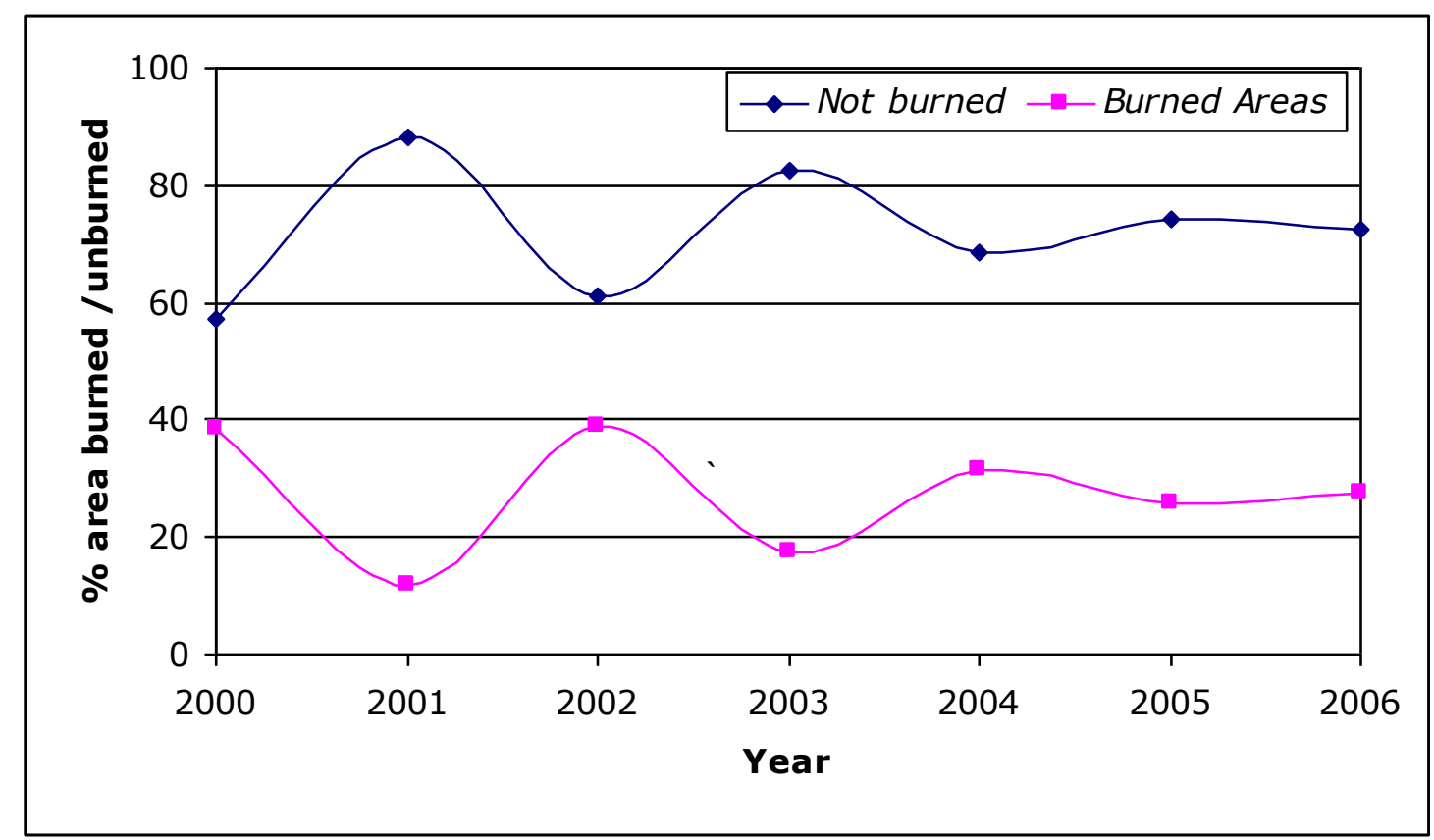

Figure 3: Trends in mapped burnt areas from 2000 to 2006

\subsection{Fire frequency mapping}

A fire frequency map was subsequently produced from the burnt area maps. Firstly the burnt area maps were converted into binary (presence or absence of fire) whereby fire presence was designated by one (1) and no fire by zero (0). These maps were therefore added in a GIS to obtain the fire frequency map (Figure 5) below.

The highest fire frequency (>4) in Hwange National Park was found to be at areas closest to the park boundary and especially so in the north, north-east and some central portions of the park. Table 2 below details the areas and percentage occupied by different fire frequencies. Areas with the highest fire frequency (7) occupy only $0.003 \%$ of the park, with the largest area (31.44\%) having experienced at least 2 fires within the 7 year period under study. Cumulatively, $86 \%$ of the park had experienced at least a single fire within the 7 year period with $14 \%$ of the park not experiencing any fire at all. For management purposes, this implies that the probability of having a fire in the park is still very high, hence management of fire occurrence is critical both for the wildlife and the vegetation within the park. Additionally, special attention has to be paid to fire activities within the adjacent populated areas in the north and north east of the park since they experienced high frequency of fires. 

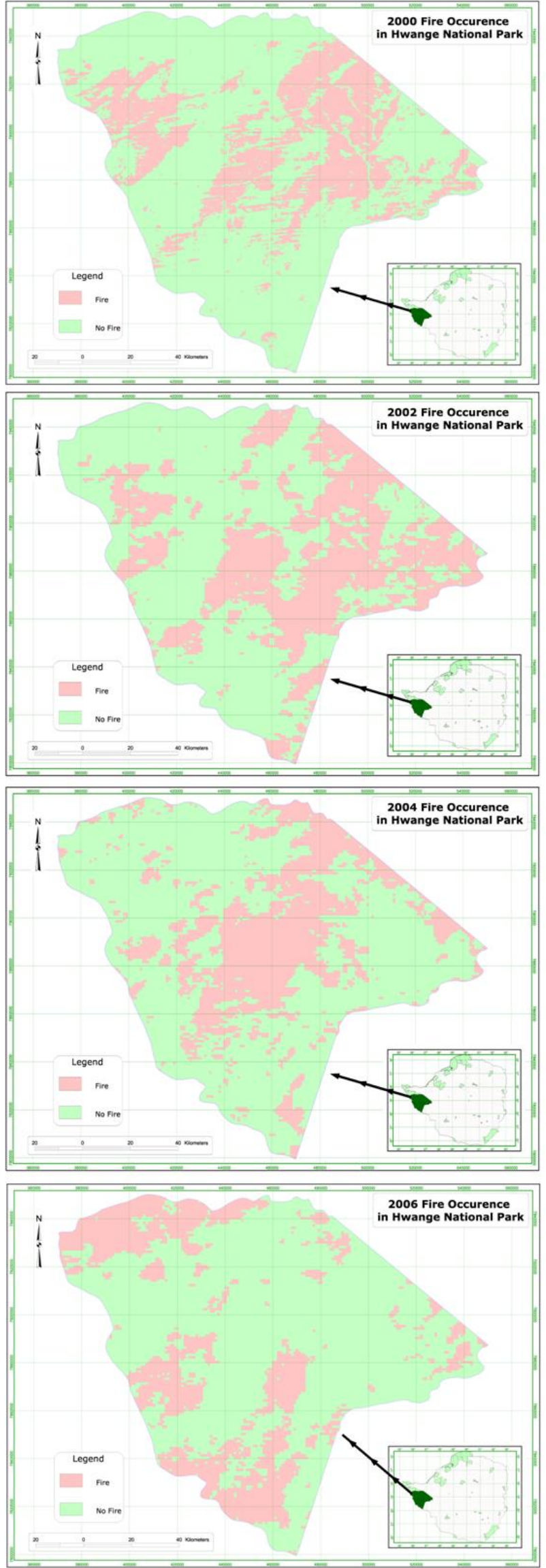
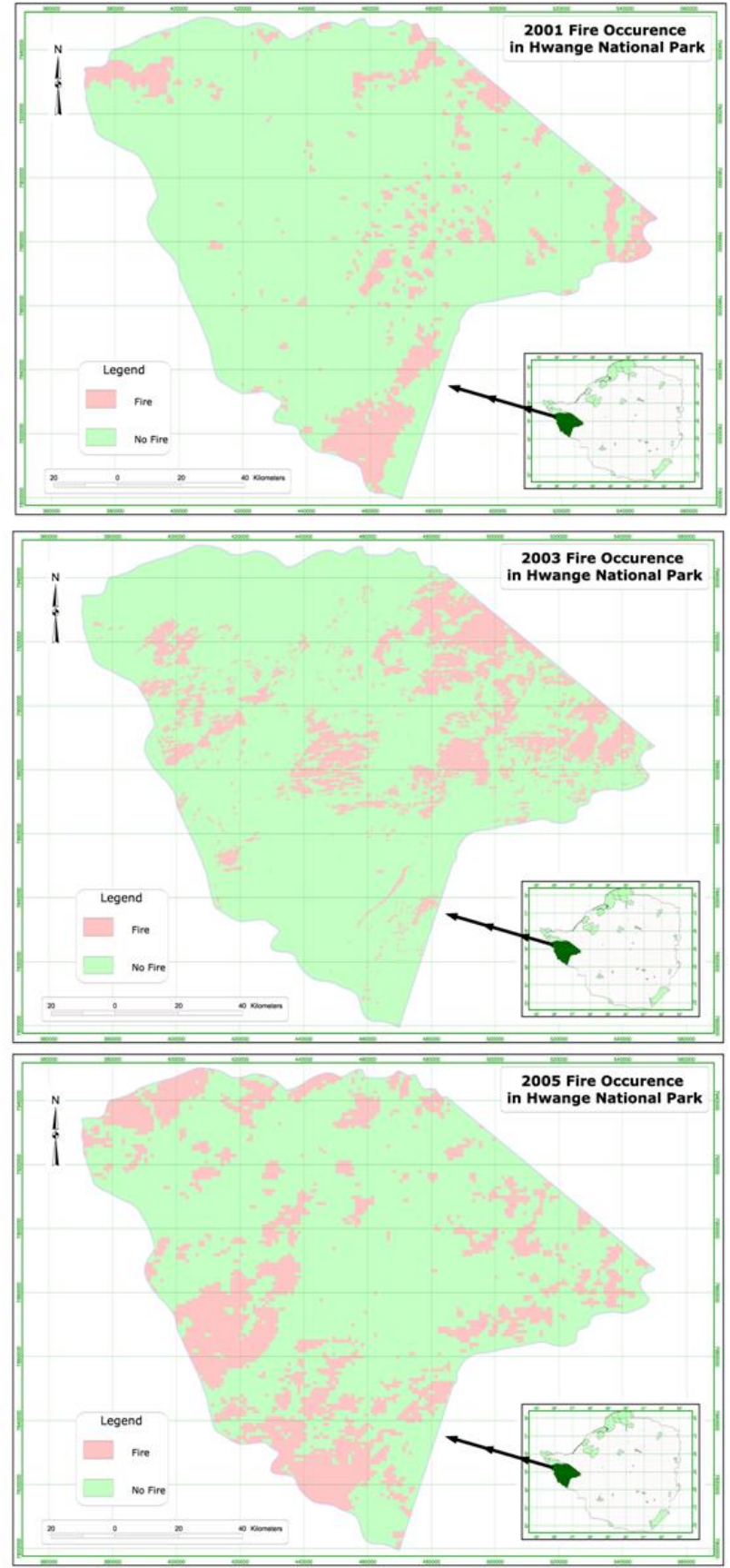

Fire occurrence in Hwange National Park from 2000 to 2006 derived from MODIS Images through Linear pixel un-mixing

Figure 4: Fire occurrence from 2000 to 2006 derived from MODIS imagery 


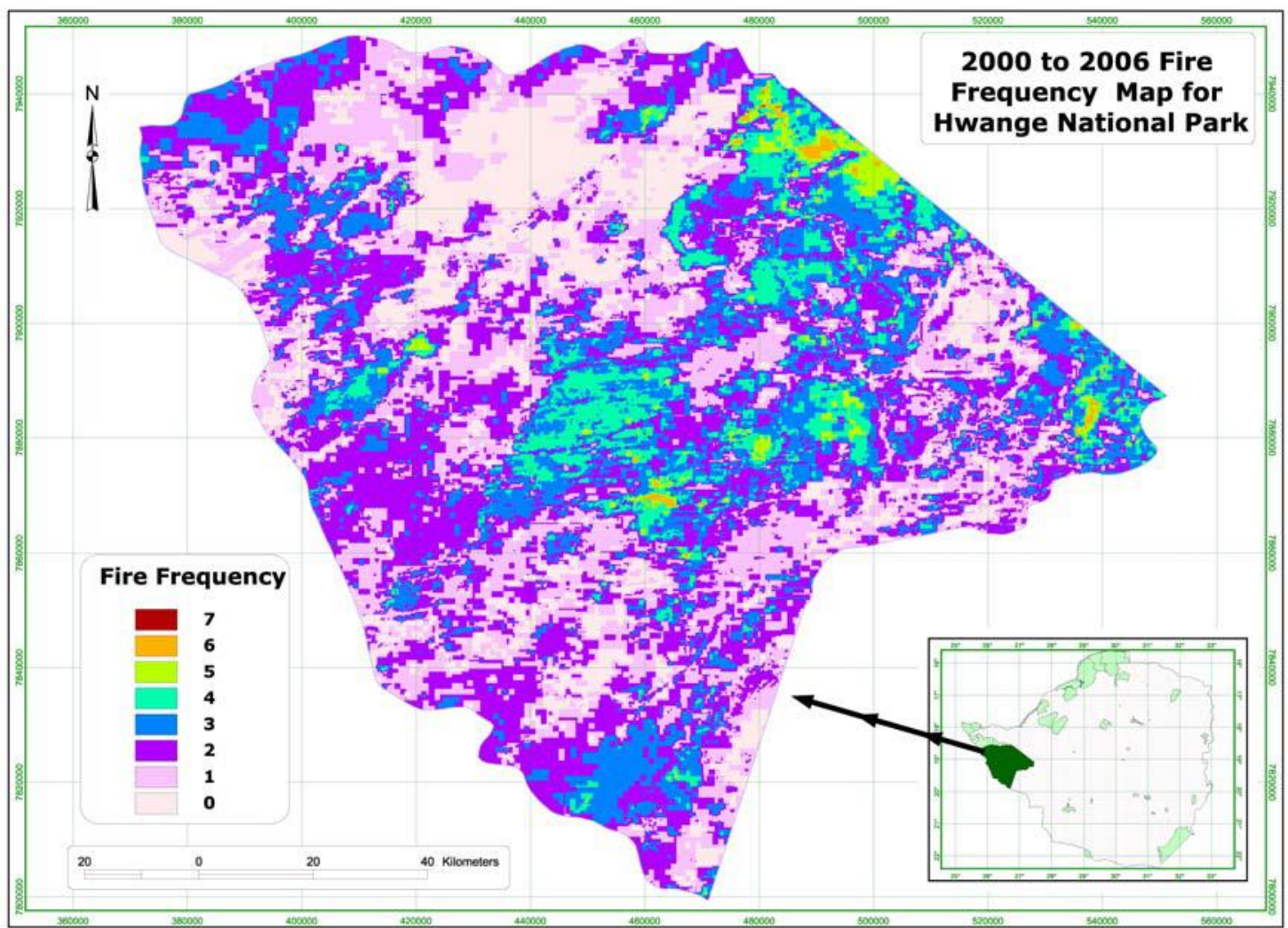

Figure 5: Fire frequency map for Hwange National Park from 2000 to 2006

Table 2: Areas occupied by different fire frequencies within Hwange National Park

\begin{tabular}{|c|c|c|c|}
\hline $\begin{array}{c}\text { Fire } \\
\text { Frequency }\end{array}$ & $\begin{array}{c}\text { Burnt area } \\
(\mathbf{k m 2})\end{array}$ & $\begin{array}{c}\text { Burnt area } \\
(\boldsymbol{\%})\end{array}$ & $\begin{array}{c}\text { Cumulative } \\
\text { Percentage }\end{array}$ \\
\hline 7 & 0.378 & 0.0026 & 0.0026 \\
\hline 6 & 39.47 & 0.27 & 0.27 \\
\hline 5 & 214.97 & 1.46 & 1.73 \\
\hline 4 & 1050.63 & 7.14 & 8.87 \\
\hline 3 & 2719.50 & 18.47 & 27.34 \\
\hline 2 & 4628.73 & 31.44 & 58.79 \\
\hline 1 & 4008.53 & 27.23 & 86.02 \\
\hline 0 & 2058.54 & 13.98 & 100.00 \\
\hline
\end{tabular}

\subsection{Accuracy assessment}

Validation of classification results involves statistical accuracy assessment of classified data, in order to measure the agreement of the classified image with the field observed data ("ground truth") using a classification error matrix (also called confusion matrix). Overall, accuracy was computed by dividing the total number of correctly classified pixels by the total number of reference pixels (Congalton and Green, 1999, Khorram et al., 2000). The classification error matrix was calculated using recorded data on observed fire occurrences 
available only from 2002 to 2006 . Unfortunately data on observed fire occurrences for the years 2000 and 2001 was not available from the park records. For the period 2002 to 2006, the overall accuracy obtained ranged from 88\% (2002); 90\% (2003); 92\% (2004); 96\% (2005) and $98 \%$ in 2006. The observed differences on overall accuracy, despite using the same images and time of acquisition, could be attributable to possible inconsistencies in collecting fire occurrence data ("ground truthing") by the park rangers. This fire information, used for accuracy assessment was collected by national park rangers during patrols but however, there was no noted systematic way of recording the fire occurrence information.

\section{Conclusions}

We have demonstrated the use of MODIS satellite imagery to map the occurrence of burnt areas from 2000 to 2006 in savannah ecosystems using linear pixel unmixing. A fire frequency map of Hwange National Park was produced showing areas likely to have repeated fires over several years. The advancement of geospatial technologies and capabilities, therefore, allow managers to make decisions based on the most current information available. Long-term and frequently updated fire maps are needed for land use, forestry, atmospheric chemistry, global climate, fire management studies and applications. The fire products are also important input for global change analysis as underlined by Malingreau and Gregoire, (1996) and Andreae, (1991). Among areas that could improve fire research are use of permanent satellites and finer spatial resolution (Malingreau and Gregoire, 1996, Hao and Liu, 1994). The study is in agreement with an earlier study that utilised AVHRR in Levante, Spain, which is in the Mediterranean climatic region (Quintano et al., 2005) in focusing on regional and local fire products instead of global and continental focus as with most fire products. The study can go further and look at other aspects such fire risk analysis and effects of fire on different vegetation species within the park. Remote sensing and GIS have, therefore, demonstrated their importance in monitoring and management of fire hazards even in inaccessible regions as wildlife domiciled national parks.

\section{REFERENCES}

ADAMS, J. B., M. O. SMITH, AND P. E. JOHNSON 1986. Spectral Mixture Modeling: A New Analysis of Rock and Soil Types at the Viking Lander 1 Site. Journal Geophysical Research, 91. ANDREAE, M. O. 1991. Biomass burning: its history, use, and distribution, and its impact on environmental quality and global climate. In: LEVINE, J. S. (ed.) Global Biomass Burning: Atmospheric, Climatic and Biospheric Implications. Cambridge, MA, USA.: MIT Press.

ANDREAE, M. O. 1997. Emissions of trace gases and aerosols from southern African savanna fires. In: VAN WILGEN, B. W., ANDREAE, M. O., GOLDAAMMER, J. G. \& LINDSAY, J. A. (eds.) Fire in southern African savannas. Johannesburg: Witwatersrand University Press. 
ARINO, O. \& ROSAZ, J. M. The ATSR World Fire Atlas and a Synergy with POLDER Aerosol Products. Proceedings of the International Workshop on the Applications of the ERS Along Track Scanning Radiometer, 23-25 June 19991999 ESRIN, Frascati,.

BATESON, C. A., ASNER, G. P. \& WESSMAN. C. A 2000. Endmember bundles: a new approach to incorporating endmember variability into spectral mixture analysis. IEEE Transactions on Geoscience and Remote Sensing, 38.

BRIVIO, P. A., GREGOIRE, J. M., CROS, B., GALY-LACAUX, C. \& LACAUX, J. P. 1999. A rose analysis method relating air chemistry to fire distribution in tropical Africa. Atmospheric research, 50, 81-104.

CAMPBELL, J. B. 1996. Introduction to Remote Sensing, Taylor \& Francis Group.

CONGALTON, R. G. \& GREEN, K. 1999. Assessing the Accuracy of Remotely Sensed Data: Principles and Practices., New York, Lewis Publishers.

CONGALTON, R. G. \& GREEN, K. 2008. Assessing the accuracy of remotely sensed data: Principles and Practices, Boca Raton, Florida, CRC Press.

CRUTZEN, P. J. \& ANDREAE, M. O. 1990. Biomass burning in the tropics: Impact on atmospheric chemistry and biogeochemical cycles. Science, 250, 1669-1678.

CRUTZEN, P. J. \& GOLDAMMER, J. G. 1993. Fire in the Environment: the Ecological, Atmospheric, and Climatic Importance of Vegetation Fires, New York, Wiley.

CUMMING, D. H. M., FENTON, M. B., RAUTENBACH, I. L., TAYLOR, R. D., CUMMING, G. S., CUMMING, M. S., DUNLOP, J. M., FORD, G. S., HOVORKA, M. D., JOHNSTON, D. S., KALCOUNIS, M. C., MAHLANGA, Z. \& PORTFORS, C. V. 1997. Elephants, woodlands and biodiversity in miombo woodland in southern Africa. South African Journal of Science 93, 231 236.

DWYER, E., PEREIRA, J. M. C., GREGOIRE, J. M. \& DACAMARA, C. C. 1999. Characterization of the spatio-temporal patterns of global fire activity using satellite imagery for the period April 1992 to March 1993. Journal of Biogeography, 27, 57-69.

DWYER, E., PINNOCK, S. \& GREGOIRE, J. M. 2000. Global spatial and temporal distribution of vegetation fire as determined from satellite observations. International Journal of Remote Sensing, , 21, 1289-1302.

ENVI. 2006. ENVI 4.3 online help [Online]. Available: http://www.ittvis.com/.

ENVIRONMENTAL MANAGEMENT ACT. 2002. Available: http://www.parlzim.gov.zw/cms/Acts/Title20_LAND,_WATER_AND_THE_ENVIRONMENT/E NVIRONMENTAL_MANAGEMENT_ACT_20_27.pdf.

FOODY, G. M. 2002. Hard and soft classifications by a neural network with a non-exhaustively defined set of classes. International Journal of Remote Sensing.

FOREST ACT. 1990. Available: http://www.parlzim.gov.zw/cms/Acts/Title19 ANIMALS, PLANTS AND FORESTRY/FORES T ACT 19 05.pdf.

FROST, P. G. H. Fire in Southern African woodlands: origins, impacts, effects and control. In: 138, F. F. P., ed. FAO Meeting on Public Policies Affecting Forest Fires, 1999. 181-205.

GAMBIZA, J., CAMPBELL, B. M. \& MOE..., S. R. 2005. Fire behaviour in a semi-arid Baikiaea plurijuga savanna woodland on Kalahari sands in western Zimbabwe: research letter. South African Journal ....

GANDIWA, E. \& KATIVU, S. 2009. Influence of fire frequency on Colophospermum mopane and Combretum apiculatum woodland structure and composition in northern Gonarezhou National Park, Zimbabwe. Koedoe - African Protected Area Conservation and Science. 
GIGLIO, L., KENDALL, J. D. \& MACK, R. 2003. A multi-year active fire data set for the tropics derived from the TRMM VIRS. International Journal of Remote Sensing, 24, 4505-4525.

GOLDAMMER, J. G. 1990. Fire in the Tropical Biota: Ecosystem Processes and Global Challenges, Berlin, Springer-Verlag.

HAO, W. M. \& LIU, M. H. 1994. Spatial and temporal distribution of tropical biomass burning. $G$. Biochem. Cycles, 8, 495-503.

HYDE, M. A., WURSTEN, B. T. \& BALLINGS, P. 2010. Flora of Zimbabwe: Outing no. 6: Visit to Hwange National Park and Bulawayo [Online]. 06 June 2014].

JUSTICE, C. 1994. African savannas and the global atmosphere, research agenda. In: JUSTICE, C. (ed.) Global Change Report. Stockholm: IGBP.

JUSTICE, C. O., GIGLIO, L. \& KORONTZI, S. 2002. The MODIS fire products. Remote Sensing of Environment, 83, 244-262.

KAUFMAN, Y. J., JUSTICE, C. O., FLYNN, L. P., KENDALL, J. D., PRINS, E. M., GIGLIO, L., WARD, D. E., MENZEL, W. P. \& SETZER, A. W. 1998. Potential global fire monitoring from EOS-MODIS. Journal of Geophyical Research.- Atmospheres, 103, 32215- 32238.

KESHAVA, N. 2003. A survey of spectral unmixing algorithms. Lincon Laboratory Journal, 14, 5578.

KHORRAM, S., KNIGHT, J., DAI, X., YUAN, H., CAKIR, H. I. \& MAO, Z. Issues Involved in the Accuracy Assessment of Large Scale Land Use/Land Cover Mapping and Monitoring In: PROCEEDINGS, I., ed. Remotely Sensed Data. Geoscience and Remote Sensing Symposium, 2000. IEEE $2000 \mathrm{Int}$.

KUSANGAYA, S., WARBURTON, M. L., VAN GARDEREN, E. A. \& JEWITT, G. P. W. 2013. Impacts of Climate Change on Water Resources in Southern Africa: A Review. Journal of Physics and Chemistry of the Earth.

LEVINE, J. S. 1991. Global biomass burning. Atmospheric, Climatic and Biospheric Implications, Cambridge, MIT Press.

LEVINE, J. S. 1996. Biomass burning and global change. Remote Sensing, Modeling and Inventory Development, and Biomass Burning in Africa, Cambridge, MIT Press.

LOUPPE D., OATTARA, N. \& COULIBALY, A. 1995. The effects of brush fires on vegetation. The Aubréville fire plots after 60 years. Commonwealth Forestry Review, 74, 288-291.

MALINGREAU, J. P. \& GREGOIRE, J. M. 1996. Developing a global vegetation fire monitoring system for global change studies: A framework. Remote Sensing and Modeling of Biomass Burning, and Biomass Burning in the Boreal Forest., The MIT Press,.

MARION, V., FRITZ, H., DUBOIS, S., KANENGONI, K., ALLEAUME, S. \& SAÏDI, S. 2006. Vegetation structure and ungulate abundance over a period of increasing elephant abundance in Hwange National Park, Zimbabwe. J. of Trop. Eco., 23, 87-93

MASOCHA, M., SKIDMORE, A. K., POSHIWA, X. \& PRINS, H. H. T. 2011. Frequent burning promotes invasions of alien plants into a mesic African savannah. Biological Invasions, 13, 16411648 .

NASA. 2013. MODIS: Specifications [Online]. Available: http://modis.gsfc.nasa.gov/about/specifications.php [Accessed 30 June 2014].

NAVASHNI, G. 2003. Fire Management in the Kruger National Park. Arid Lands Newsletter [Online]. Available: http://ag.arizona.edu/oals/ALN/aln54/govender.html.

PARKS AND WILDLIFE ACT. 1991. Available: http://www.parlzim.gov.zw/cms/Acts/Title20_LAND,_WATER_AND_THE_ENVIRONMENT/P ARKS_AND_WILD_LIFE_ACT_20_14.pdf. 
PRICOPE, N. G. \& BINFORD, M. W. 2012. A spatio-temporal analysis of fire recurrence and extent for semi-arid savanna ecosystems in southern Africa using moderate-resolution satellite imagery. Journal of Environmental Management, , 100, 72-85.

PRINS, E. M., FELTZ, J. M., MENZEL, W. P. \& WARD, D. E. 1998. An overview of GOES-8 diurnal fire and smoke results for SCAR-B and 1995 fire season in South America. J. of Geophys. Res., 10331 821-31835.

QUINTANO, C., FERNÁNDEZ-MANSO, A., SHIMABUKURO, Y. \& PEREIRA, G. 2012. Spectral unmixing. International Journal of Remote Sensing.

QUINTANO, C., SHIMABUKURO, Y., FERNÁNDEZ, A. \& DELGADO, J. 2005. A spectral unmixing approach for mapping burned areas in Mediterranean countries. International Journal of Remote Sensing.

ROY D., J. Y., LEWIS P.E. \& C.O., J. 2005. Prototyping a global algorithm for systematic fire affected area mapping using MODIS time series data. Remote Sensing of Environment, 97, 137162.

ROY, D. P., LEWIS, P. E. \& JUSTICE, C. O. 2002. Burned area mapping using multi-temporal moderate spatial resolution data - a bi-directional reflectance model-based expectation approach. . Remote Sensing of Environment, 83, 263-286.

SCHOLES, R. J. \& WALKER, B. H. 1993. An African Savanna: Synthesis of the Nylsvley Study, Cambridge, Cambridge University Press.

SILVA, J. M. N., PEREIRA, J. M. C., CABRAL, A. I., SÁ, A. C. L., VASCONCELOS, M. J. P., MOTA, B. \& GRÉGOIRE, J. M. 2003. An estimate of the area burned in Southern Africa during the 2000 dry season using SPOT-VEGETATION satellite data. . Journal of Geophysical Research., 108, 8498.

SIMON, M., PLUMMER, S., FIERENS, F., HOELZEMANN, J. \& ARINO, O. 2004. Burnt area detection at global scale using ATSR-2: the GLOBSCAR products and their qualification. J. of Geophy. Res., 109.

TAFENGENYASHA, C. 1997. Tree loss in the Gonarezhou National Park (Zimbabwe) between 1970 and 1983. Journal of Environmental Management, 49, 355-366.

TANSEY, K., GREGOIRE, J. M., BINAGHI, E., BOSCHETTI, L., BRIVIO, P. A., ERSHOV, D., FLASSE, S., FRASER, R., GRAETZ, D., MAGGI, M., PEDUZZI, P., PEREIRA, J., SILVA, J., SOUSA, A. \& STROPPIANA, D. 2004. A global inventory of burned areas at $1 \mathrm{~km}$ resolution for the year 2000 derived from SPOT VEGETATION data. Climate Change, 67, 345-377.

TANSEY, K., GREGOIRE, J-M., PEREIRA, J.M.C., DEFOURNY, P., LEIGH, R., PEKEL, J-F., BARROS, A., SILVA, J., VAN BOGAERT, E., BARTHOLOMÉ, E., BONTEMPS, S. 2007. L3JRC - A global, multi-year (2000-2007) burnt area product (1 km resolution and daily time steps). Remote Sensing and Photogrammetry Society Annual Conference 2007. Newcastle upon Tyne, UK.

WANG, L. \& JIA, X. 2009. Integration of soft and hard classifications using extended support vector machines. Geoscience and Remote Sensing Letters.

XIN, M., GONG, P., SWOPE, S., PU, R., CARRUTHERS, R., ANDERSON, G. L., HEATON, J. S. \& TRACY, C. R. 2006. Estimation of yellow starthistle abundance through CASI-2 hyperspectral imagery using linear spectral mixture models. Remote Sensing of Environment, 101, 329-341. 